\title{
POTRZEBY I OCZEKIWANIA W ZAKRESIE BADAŃ PROWENIENCYJNYCH
}

Określenie roli ksiażki w „kształtowaniu kultury umysłowej, artystycznej i moralnej społeczeństwa" nie może się obejść bez prowadzenia badań proweniencyjnych - słusznie stwierdziła Barbara Bieńkowska rozpoczynając w 1975 roku edycję serii pt. „Z badań nad polskimi księgozbiorami historycznymi”" ${ }^{1}$. Tezę tę potwierdziły artykuły zamieszczane w kolejnych dziesięciu tomach tego cennego i pożytecznego wydawnictwa warszawskiego, m.in. ukazującego podstawy warsztatu naukowego bibliologa.

Pożyteczne zatem powinno się okazać wskazanie pól badawczych dotąd penetrowanych metodą proweniencyjną oraz nowych kierunków i możliwości w związku z zastosowaniem technik komputerowych w badaniach nad ksiażką, biblioteką i informacją naukową ${ }^{2}$.

\section{Dotychczasowe kierunki badań proweniencyjnych w Polsce}

Odkrywanie śladów obiegu książki oraz refleksji jej czytelników w postaci zapisów lub znaków umieszczanych na niej po ukończeniu prac edytorskich (cechy indywidualne, postnakładowe książi drukowanej) łączyło się i lączy się dotąd zazwyczaj z pracami bądź: 1) dokumentacyjno-informacyjnymi (odzwierciedlającymi stan posiadania) bądź 2) odtwarzaniem warsztatu pracy właściciela księgozbioru lub książki, czy wreszcie z 3) opiniami czytelników. Te trzy typy badań naukowych odpowiadają w zasadzie głównym, istniejącym kierunkom badawczym. Trzeba tu dodać, że badania proweniencyjne zapoczątkowane na ziemiach polskich na przelomie $X I X X X X$ wieku, na szerszą skalę rozwinęly się dopiero po drugiej wojnie światowej w oparciu o założenia metodologiczne szkoły historyków (zwłaszcza literatury), bibliologów oraz socjologów ${ }^{3}$.

1) Najwięcej powstało opracowań dokumentacyjno-informacyjnych w wyniku prowadzenia prac porządkowych w bibliotekach, archiwach, muzeach czy zbiorach prywatnych. Owe kartoteki, katalogi (najczęściej rękopiśmienne na „cedułkach" jak nazywał kartoteki Joachim Lelewel), rzadziej publikowane, czasem inne wydawnictwa o zbiorach (np. bibliofilskie o ekslibrisach, superekslibrisach, sygnetach drukarskich i wydawniczych, etc.) - zazwyczaj obejmują tylko wiadomości o najcenniejszych partiach kolekcji (zbiory specjalne, zwłaszcza rękopisy, inkunabuly, polonica XVI wieku itd.).

Prowadzenie dokumentacji tego typu wymaga wielu kwalifikacji oraz wszechstronnej erudycji. Zgodnie potwierdzają ten fakt wybitni polscy teoretycy posługu- 
jący się metodą proweniencyjną, rangi wspomnianego już Joachima Lelewela, Aleksandra Birkenmajera, Alodii Kaweckiej-Gryczowej, Bronisława Kocowskiego, Rudolfa Kotuli, Kazimierza Piekarskiego, Anny Lewickiej-Kamińskiej i in. Na niezbędność precyzji w tych badaniach, ich pracochłonność, długoterminowość, znajomość warsztatu pracy historyka, historyka sztuki, socjologa - obok umiejętności księgoznawcy - zwracają uwagę wszyscy badacze stykający się z opracowaniem dokumentacji zbiorów.

Po drugiej wojnie światowej, wśród podejmowanych prac widać dążenie do poszerzenia walorów informacyjnych opracowań katologowych. Wynika stąd publikowanie informacji łączonej dla zbiorów o różnej lokalizacji. Wzorcowym przykładem może tu być wydawnictwo o inkunabułach przechowywanych w bibliotekach $w$ Polsce, $z$ osobnym tomem poświęconym wynikom badań proweniencyjnych, od lat oczekującym na druk ${ }^{4}$. Wśród autorów tego rodzaju opracowań znajdują się historycy, latyniści, poloniści, historycy sztuki i in. Notowania proweniencyjne odzwierciedlające zapisy i znaki na poszczególnych książkach. komasowane są drogą indeksów, zgodnie $z$ regułami jasno wyłożonymi w doskonałym metodycznie artykule Marii SipayHo ${ }^{5}$. Kolejna tendencja w tego typu pracach badawczych metodą proweniencyjna jest odchodzenie od opracowań jednego lub dwóch autorów na rzecz wieloosobowych zespołów specjalistów różnych dziedzin wiedzy, ciągle jednak najczęściej praktyków bibliotekarzy, związanych pracą zawodową z analizowanymi proweniencjami księgozbiorów.

Biblioteczne badania proweniencyjne pozwalaja zatem na systematyczną analizę księgozbiorów o określonej lokalizacji i dostarczają materiały o trwałej wartości źródłowej, ważne dla badań dziejów książki i bibliotek, socjologii książki, a tym samym dia kultury narodowej. Im większe zbiory biblioteczne czy archiwalne w Polsce, tym prace proweniencyjne są mniej zaawansowane i radko wychodzą poza kolekcje poloników. Podobnie jest zresztą na całym świecie. Szczególnie poszkodowany jest wiek XIX oraz XX, badane tylko pod kątem określonych tematów lub wyłączonych w bibliotekach księgozbiorów uczonych, pisarzy lub innych wybitnych osobistości. W publikowanych katalogach, na tle edycji typowych $z$ bogatym i różnorodnym warsztatem pomocniczym (zestawienia, indeksy, konkordancje, etc.), wyróżniają się wydania bibliofilskie, jak np. „Spis druków Epoki Jagiellońskiej w zbiorze Emeryka hrabiego Hutten Czapskiego" w opracowaniu Feliksa Kopery (Kraków 1900). Materiał ilustracyjny stanowi często w tego typu dokumentacji ważny element potwierdzający wiarygodność materiału źródłowego i uzupełnienie opisów słownych.

Rozwijający się kierunek tych badań proweniencyjnych łączy się z pytaniem o właściciela lub czytelników/użytkowników książek bez względu na miejsce przechowywania księgozbioru. Skala trudności i pracochłonności badań proweniencyjnych wówczas znacznie wzrasta. Poszukiwania odbywają się w różnych instytucjach, miastach, a często i krajach. Wystarczy tu wspomnieć na przykład książki zmieniające właścicieli w związku z „potopem szwedzkim", restrykcjami po powstaniach narodowych. Najbardziej typowym przykładem jest rozproszenie biblioteki braci Załuskich czy króla Zygmunta Augusta ${ }^{6}$. 
Dodatkową trudność w tego typu badaniach stwarza samo dotarcie do przedmiotu badań, czyli książek opatrzonych interesującymi nas znakami proweniencyjnymi. W efekcie często te poszukiwania powodują konieczność przeglądania setek woluminów nim natrafi się na ten z konkretnymi znakami proweniencyjnymi. Tak np. w kilkunastotysięcznych zbiorach Emeryka Hutten Czapskiego odszukano unikatowy egzemplarz z biblioteki króla Jana III Sobieskiego' ${ }^{\prime}$. Dodatkową przeszkode w prowadzeniu takich badań proweniencyjnych może stanowić dostęp z autopsji do zbiorów, konieczność penetrowania magazynów, względy konserwatorskie ochrony zbiorów etc. Z tymi trudnościami musi się liczyć badacz, zwłaszcza jeżeli poszukiwania wypadnie mu prowadzić poza miejscem pracy, w nieznanym terenie. Badania tego typu, zwykle jako pomocnicze przy monograficznych opracowaniach, raz podjęte - najczęściej jednak wciaggają na dłuższy czas uczonych, dają satysfakcję i przynoszą nader ciekawe wyniki.

2) Bardzo często dotarcie do księgozbioru wybitnej osobistości świata nauki, kultury, dostojnika świeckiego lub kościelnego pozwala przybliżyć jego warsztat pracy, otrzymać informacje niemożliwe do uzyskania inną drogą. Ten aspekt badań doceniło wielu poważnych specjalistów, którzy metodą proweniencyjną uzupełnili studia monograficzne. Przeglądu takich opracowań dostarczyla seria „Książka w Dawnej Kulturze Polskiej" ze wzorcowymi opracowaniami Anny Lewickiej-Kamińskiej o "Renesansowym księgozbiorze Mikołaja Czepla w Bibliotece Jagiellońskiej" (1956 r.), Leszka Hajdukiewicza o "Bibliotece Macieja z Miechowa” (1960 r.) oraz tego samego autora „Księgbżbiór i zainteresowania bibliofilskie Piotra Tómickiego na tle jego działalności kulturalnej” (1961); Kamili Schuster „Biblioteka Łukasza Opalińskiego marszałka nadwornego koronnego (1612-1662)" (1971 r.) oraz wspominane łamy prac zbiorowych pod redakcją Barbary Bieńkowskiej pt. „Z badań nad polskimi księgozbiorami historycznymi" (t. 1-14). Sporadycznie wyniki badań proweniencyjnych ogłaszane są w monografiach w serii "Ksiażki o Książce" lub w postaci innych druków zwartych, najczęściej jednak publikowane są w formie artykułów odnotowanych w Polskiej Bibliografii Bibliologicznej ${ }^{8}$. Ciekawe proweniencje dodają blasku kolekcjom bibliofilskim i w opisywanych księgozbiorach eksponowane sa znaki i zapisy rzadkie lub wybitnych osobistości tzw. „rara”. Doskonalenie warsztatu badacza proweniencji pozwala uzyskiwać coraz to nowe efekty interpretacyjne. Można dzięki nim odsłonić np. tajniki pracy bibliotekarza - właściciela księgozbiorów (np. Emeryk Hutten Czapski jako bibliotekarz) ${ }^{9}$, malarza i dramaturga (Stanisław Wyspiański i jego księgozbiór) ${ }^{10}$, spróbować dokonać testu kultury wybranej epoki (badania np. Barbary Kamińskiej-Czubałowej) ${ }^{11} \mathrm{i}$ in.

3) Różnorodność typów zapisów proweniencyjnych pozwala wyodrębnić osobny i o dużych walorach poznawczych kierunek badań nad czytelnictwem. Tym razem metoda proweniencyjna może być wybrana jako główna (np. propozycje teoretyczne i doświadczenia badawcze Karola Głombiowskiego) lub jako pomocnicza $w$ badaniach bibliograficznych (por. Krystyna Bednarska-Ruszajowa $i$ jej badania ksiąg wypożyczeń) ${ }^{12}$. Metoda proweniencyjna może też być ważnym wsparciem dla badań czytelnictwa metodami socjologiczno-statystycznymi ${ }^{13}$. Na podstawie badań proweniencji można też zebrać i publikować materiały źródłowe, ważne dla innych badaczy książki. Odkrywa się bowiem przy okazji np. ekslibrisy, 
superekslibrisy, pieczątki, czasami też napisy i notki właścicieli, jak np. specjalne teksty broniące przed złodziejami książek ${ }^{14}$.

Postęp w badaniach nad książką, biblioteką i informacją naukową sprzyjał krzyżowaniu metod dla osiagnnięcia ciekawych i użytecznych społecznie wyników. Do najoryginainiejszych należat pomyst Edwarda Chwalewika (1873-1956) wybitnego bibliofila, bibliografa, bibliotekarza, z wykształcenia prawnika, badacza ekslibrisów. Zafascynowany kolekcjami zbiorów polskich, przerażony zniszczeniami podczas I wojny światowej, opracował wydawnictwo do dzisiaj nie zastapione pt. „Zbiory polskie, archiwa, biblioteki, gabinety, galerie, muzea i inne zbiory pamiątek przeszłości w ojczyźnie i na obczyźnie w układzie alfabetycznym wg miejscowości" (wyd. 1 w 1916 r., wyd. 2 t. 1-2 1926-1927 r.). Dzisiaj ocenić należy tę pracę jako wiekopomną. Materiały zostały zebrane za pomocą ankiet danych bibliograficznych i proweniencyjnych. Układ topograficzno-proweniencyjny pozwala na odnalezienie pod nazwą miejscowości, następnie instytucji, nazwiskiem wlaściciela - wiadomości o wszystkich znaczniejszych dla kultury polskiej zbiorach rękopiśmiennych i drukowanych książek oraz muzealiów. Powstał w ten sposób dokument, którego wartość można dopiero w pełni docenić $w$ obliczu strat w związu z II wojną światową. Ów zapis przypomina o zbiorach rozproszonych po świecie, dopinguje do ich odszukania i stworzenia aktualnej informacji, nakłania do otworzenia nowej karty badań proweniencyjnych nad polskimi księgozbiorami historycznymi, na miarę nowych możliwości i oczekiwań wynikających z sytuacji Polski po 1989 roku.

\section{Nowe moźliwości badań proweniencyjnych w Polsce po 1989 roku w zestawieniu w inicjatywami na świecie oraz wykorzystaniem nowoczesnych technik komputerowych}

Otworzenie granic Polski po zwycięstwie „Solidarności”, perspektywa naprawdę wolnej nauki polskiej, ożywiła inwencję twórczą i organizacyjną Polaków, pozwoliła zrywać z szablonami, podejmować decyzje ważne dla odrodzenia niezależnej myśli, a też badań proweniencyjnych. Od dawna kiełkujący zamysł utworzenia naukowego towarzystwa badaczy książki, biblioteki i informacji naukowej trafił na sprzyjający klimat i 1 września 1989 roku Sąd Wojewódzki w Warszawie zarejestrował Polskie Towarzystwo Bibliologiczne. W pierwszym zarządzie znaleźli się inicjatorzy pomysłu - prof. Barbara Bieńkowska i prof. Krzysztof Migoń. W ślad za centralą powstały oddziały w Warszawie (prezes prof. Paulina Buchwald-Pelcowa), w Łodzi (prof. Janusz Dunin), we Wroctawiu (prof. Józef Szczepaniec), w Krakowie (dr hab. Maria Kocójowa), a czasopismo „Nowiny Polskiego Towarzystwa Bibliologicznego" zaczęło przynosić informacje o planach naukowych. Poczesne miejsce zajęty wśród nich badania nad polskimi księgozbiorami przemieszczonymi i zaczęła kiełkować idea m.in. reedycji dzieła Edwarda Chwalewika i poszerzenia programu badań proweniencyjnych nad polskimi księgozbiorami historycznymi, starannie podsycana przez Panią Prezes prof. Barbarę Bieńkowską. Usunięcie barier w informacji, udostępnienie księgozbiorów do celów naukowych bez względu na to gdzie się znajdują - oto założenia tego pożytecznego planu badawczego, 
wielokrotnie dyskutowanego na spotkaniach członków Polskiego Towarzystwa Bibliologicznego. Środowisko krakowskie włączyło do tych pomysłów projekt ankiety badań proweniencyjnych, przystosowany do zapisu komputerowego i tworzenia baz danych (referowany w Warszawie w grudniu 1990 r. przez piszącą te słowa).

W trakcie ożywionej dyskusji ujawnił się brak przygotowania do tego typu prac naukowych ze względu na nieposiadanie urządzeń technicznych w Pracowni Naukowej PTB, powołanej przy Bibliotece Narodowej; brak przeszkolenia pracowników, wzorów ankiet i odpowiednich programów komputerowych. Wszyscy uczestnicy spotkania, mimo małej wiary w szybką realizację planów, okazali zainteresowanie unowocześnieniem badań proweniencyjnych polskich księgozbiorów historycznych.

Warto zatem odwołać się do paralelnych dążeń w świecie i spróbować określić ich glówne kierunki oraz dotychczasowe wyniki na wybranych przykładach.

W Wielkiej Brytanii zainteresowanie kolekcjami ksiażek w bibliotekach doprowadziło w 1985 roku do wydania drukiem diugo przygotowywanego informatora pt. „A Directory of Rare Book and Special Collections in the United Kingdom and the Republic of Ireland" (1 ed. Stanley Roberts, 2 ed. Moelwyn I. Williams przy współpracy Williama Dienemana z Aberystwyth i Robertsa Donaldsona z Edynburga-prezesa Rare Books Group The Library Association). Ta pokaźnych rozmiarów księga zawiera w układzie topograficznym opis narastania kolekcji, krótką ich charakterystykę oraz najwcześniejsze publikacje na temat zbiorów. Indeks miejscowości, nazw bibliotek i rzeczowy dopełniają to, jakże bliskie w koncepcji Chwalewikowi, pożyteczne dzieło o bibliotekach angielskich.

Biblioteka Polska w Londynie w zwiazku z pracami automatyzacyjnymi podjęła rekonesans dotyczący polskich księgozbiorów w Wielkiej Brytanii. Przewodnicząca Komisji Bibliotecznej Polskiego Ośrodka Społeczno-Kulturalnego w Wielkiej Brytanii Eugenia Maresch zwróciła się w 1990 roku z dwoma typami ankiet do bibliotek zawierających polskie księgozbiory. Jedne przeznaczone byty dla polskich bibliotek działających przy polskich organizacjach, parafiach etc.; drugie - skierowano do angielskich bibliotek posiadających zbiory polskie. Obecnie odpowiedzi są w opracowaniu i wyników należy się spodziewać z końcem 1991 roku $^{15}$. Należy się jednak obawiać, że stopień szczegółowości nie będzie wystarczający dla tak precyzyjnego określenia narastania i zawartości księgozbiorów polskich, jak to uczynił Moelwyn I. Williams dla księgozbiorów angielskich, a Edward Chwalewik dla zbiorów polskich w okresie międzywojennym. Najprawdopodobniej trzeba będzie dla uzyskania pełnej informacji dopełnić dane $z$ ankiet na podstawie właśnie badań proweniencji księgozbiorów polskich.

Obiecująco reklamowany w prospektach system informacji naukowej CONSPECTUS, przyjęty został do realizacji przez narodowe biblioteki w lutym 1987 roku (Francja, Niemcy, Holandia, Portugalia i Wielka Brytania, z poszerzeniem o naukowe biblioteki tych krajów oraz Austrii, Norwegii i Szwajcarii) ${ }^{16}$. Współpracą kieruje Ann E. Wade z British Library i obecnie planuje przyjęcie do tego systemu bibliotek z krajów dawnego bloku socjalistycznego. System ten dostarcza informacji o zawartości treściowej zbiorów bibliotecznych (w oparciu o klasyfikację Library of Congress), o języku księgozbiorów, uwzględnia specjalnie cenne grupy materiałów, 
jest w nim miejsce na noty proweniencyjne. W sumie przewidzianych jest ok. 2000 kategorii, 8000 haseł przedmiotowych. Można zatem zapytać system, w których bibliotekach spośród współpracujących znajdują się np. zbiory w języku polskim lub czy są i gdzie zbiory z poszczególnych dziedzin dotyczące Polski; ale nie uzyska się informacji o konkretnych tytułach. Noty proweniencyjne są wprowadzane tylko ogólne (nazwa i umiejscowienie biblioteki). Najaktywniejsze są w Anglii, w systemie CONSPECTUS, biblioteki Szkocji i naturalnie British Library (całość informacji o zbiorach). Obecnie dołączyła do prac National Library of Art Victoria and Albert Museum $^{17}$. Są plany przyłączenia bibliotek skandynawskich (Szwecja). System pochodzi z USA (Research Libraries Group, Kalifornia) i ma na celu kooperację i koordynację nabytków (m.in. cennych kolekcji „rare books”), konserwację i zabezpieczenie zbiorów (priorytety) oraz informację, m.in. o zmianach w księgozbiorach w naukowych bibliotekach na świecie. System wskazuje na dziedziny wiedzy, w których biblioteka jest najsilniejsza (najzasobniejsza) oraz braki, czyli te, w których potrzebuje pomocy (uzupełnienia zbiorów). Pola zapisów przeznaczone na określenie proweniencji nie są w całości wypełniane przy wprowadzaniu danych do systemu. Założenia systemu są bardzo atrakcyjne dla prac Polskiego Towarzystwa Bibliologicznego, ale warstwa dotycząca proweniencji ma charakter zbyt ogólny.

Podobne obserwacje wiążą się z systemem The Eighteenth Century Short Title Catalogue (ESTC), zatwierdzonym w 1977 r., gdzie aktualnie prace prowadzone są pod kierunkiem Michela J. Crumpa z British Library ${ }^{18}$. Obecnie w systemie zebrano dane z około 1000 bibliotek naukowych całego świata (w tym około $400 \mathrm{z}$ USA i Kanady), związane z lokalizacją i opisem bibliograficznym angielskich druków z XVIII w. Zebrano ponad 100000 opisów i uchwycono wielokrotne występowanie egzemplarzy (kody sygnatur bibliotek). Z Polski informacja płynie zbyt wolno (kilka tysięcy tytułów) i niestety nie przystąpiła do współpracy Biblioteka Jagiellońska, posiadająca jeden z największych w Polsce zasobów starych druków. Obszerne pola na zapisy proweniencji nie są wypełniane przy opisach, poprzestaje się na uchwyceniu lokalizacji egzemplarzy, co powoduje ograniczenia w przydatności systemu dla polskich badań proweniencyjnych. Korzystne natomiast jest powstanie wzoru projektu pola przeznaczonego na odnotowywanie proweniencji. Prace w systemie ESTC rozpoczęte w 1982 roku przewiduje się zakończyć po 15 latach, więc Polska może zwiększyć swój bank informacyjny. O postępie badań informuje czasopismo „Factotum".

Przykłady angielskie mogą więc zachęcić do prowadzenia prac nad reedycją dzieła Chwalewika, jak i świadczą o potrzebie tego typu opracowań, ukazują również piętrzące się trudności z wprowadzeniem pełnej informacji o proweniencjach do automatycznych systemów o zasięgu światowym. Prawdopodobnie jedną z przyczyn jest brak informacji w istniejących katalogach i opracowaniach oraz pracochłonność jej tworzenia.

W tej sytuacji adaptacja prac proweniencyjnych dotyczących przemieszczania polskich księgozbiorów do zapisu komputerowego winna uwzględnić doświadczenia polskie (oferty MicrolSIS, MAK), ale w sposób zapewniający kompatybilność z systemami wspólnoty europejskiej ${ }^{19}$. 


\section{Przypisy}

${ }^{1}$ B. Bieŕkowska, Wstęp, [W:] Z badań nad polskimi księgozbiorami historycznymi, z. 1, Warszawa 1975, s. 5 i nast.

${ }^{2}$ Teoretyczne podstawy badań nad książką - model bibliologii K. Migonia; badań nad biblioteką model Z. Gaca-Dąbrowskiej; nad informacją naukową - model M. Dembowskiej. Zob. stan badań: „Studia o Książce", t. 1-18, 1970-1989.

${ }^{3}$ Obecnie badania proweniencyjne wspomagaja interdyscyplinarne badania komunikacji spolecznej (np. prowadzone przez IKiCZ w Warszawie); badania kultury książki (np. prowadzone w Uniwersytecie Warszawskim pod kierunkiem Barbary Bieŕkowskiej - zob. „Studia o Książce”, t. 17) lub badania nad świadomością narodową i przemianami mentalności (np. „Ksiażka polska w okresie zaborów”, Kraków 1991 lub „Kultura książki w Krakowie doby autonomii galicyjskiej”, Wrocław 1991).

${ }^{4}$ Incunabula quae in bibliothecis Poloniae asservantur. Moderante A. Kawecka-Gryczowa, composuerunt M. Bohonos, E. Szandorowska, t. 1-2, Wrocław 1970. Inne katalogi wymienia A. Kawecka-Gryczowa w pracy „Dzieje drukarstwa w Polsce XV i XVI w. Stan badań i postulaty”, W:] Dawna ksiażka i kultura, Wrockaw 1975, s. 9-32.

${ }^{5}$ M. Sipayłto, O metodzie badań proweniencyjnych starych druków, [W:] Z badań. z. 1, s. 9-30.

${ }^{6}$ A. Kawecka-Gryczowa, Biblioteka ostatniego Jagiellona. Pomnik kultury renesansowej, Wroctaw 1988. Zob. też B. Bieńkowska, Staropolski świat książek, Wroctaw 1976.

${ }^{7}$ Muzeum Narodowe w Krakowie, sygn. Dz. VII D. XVII 2103.

${ }^{8}$ Baza danych Polska Bibliografia Bibliologiczna znajduje się w Katedrze Bibliotekoznawstwa i Informacji Naukowej Uniwersytetu Jagiellońskiego, 31-007 Kraków, ul. Gołębia 16.

${ }^{9}$ M. Kocójowa, „Pamiątkom ocalonym z burzy dziejowej”. Muzeum Emeryka Hutten Czapskiego Stańków-Kraków, Kraków 1978.

${ }^{10}$ A. Gruca, Księgozbiór Stanisława Wyspiańskiego, Kraków 1989, Biblioteka Krakowska nr 126.

${ }^{11}$ B. Kamińska-Czubalowa, Analiza semiotyczna w badaniach nad księgozbiorami historycznymi, [W:] Z problemów metodologii i dydaktyki bibliotekarstwa i informacji naukowej. Praca zb. pod red. M. Kocójowej, Kraków 1990, s. 109-122.

${ }^{12}$ K Glombiowski, Problemy historii czytelnictwa, Wroclaw 1966; Tenże, Książka w procesie komunikacji społecznej, Wrocław 1980; B. Bieńkowska, Inwentarze ksieggozbiorów prywatnych jako źródło do badań nad dziejami czytelnictwa. "Studia o Książce", 1989 t. 18, s. 65-76; K. Bednarska-Ruszajowa, Od Homera do Jana Jakuba Rousseau. W kregu lektur profesorów krakowskich okresu Oświecenia, Kraków 1991, Rozprawy habilitacyjne Uniwersytetu Jagiellońskiego nr 210. Zob. też M. Kocójowa, Krakowski świat książki doby autonomii galicyjskiej, Kraków 1990, Rozprawy habilitacyjne Uniwersytetu Jagiellońskiego nr 185.

${ }^{13}$ Instytucje - publiczność - sytuacje lektury. Studia z historii czytelnictwa pod red. J. Kosteckiego, t. 1-3, Warszawa 1989-1991.

${ }^{14}$ Np. W. Wittyg, Ex-librisy bibliotek polskich, t. 1-2, Warszawa 1903-1907; L. Gocel, Przypadki Jej Królewskiej Mości Książki, Wroctaw 1963.

${ }^{15}$ Eugenia Maresch przygotowuje specjalne opracowania wyników badań dla brytyjskiego ministerstwa w związku z otr zymaniem grantu przez Bibliotekę Polską w Londynie.

${ }^{16}$ Wywiad M. Kocójowej $z$ Ann Wade w trakcie sponsorowanego przez British Council pobytu w Wielkiej Brytanii we wrześniu 1991 r., połączony z demonstracją systemu CONSPECTUS w British Library.

${ }^{17}$ Materialy powielane na temat systemu CONSPECTUS uprzejmie udostępnione zostały przez Gillian Varley - kierownika Działu Obsługi Czytelnika National Art Library Victoria \& Albert Museum.

${ }^{18}$ M.J. Crump, Searching ESTC on Blaise-Line. A brief guide by..., ${ }_{n}$ FACTOTUM. Newsletter of the XVIII ${ }^{\text {th }}$ century STC", January 1989. 
${ }^{19}$ Mikrokomputer w bibliotece. Numer specjalny miesięcznika "Poradnik Bibliotekarza" (oprac. M. Nahotko i W. Szczęch), Warszawa [b.r.] W. Szczęch, Pakiet programów MicrolSIS i możliwości jego wykorzystania w dydaktyce, [W:] Z problemów metodologii..., s. 151-164; Materiały z konferencji pt. ${ }_{n}$ Humanista przy komputerzen , Szkoła jesienna w Karpaczu, 12-15 listopada 1991 roku, organizatorzy: Katedra Bibliotekoznawstwa i Informacii Naukowej Uniwersytetu Łódzkiego, Instytut Bibliotekoznawstwa i Informacji Naukowej Uniwersytetu Warszawskiego oraz Biblioteka Narodowa w Warszawie. 